\title{
CHARACTERIZATION OF BENZODIAZEPINE AND $\gamma$-AMINOBUTYRIC RECOGNITION SITES AND THEIR ENDOGENOUS MODULATORS
}

\author{
M. MASSO'TTI, ${ }^{*}$ A. GUIDOTTI, AND E. COSTA \\ Laboratory of Preclinical Pharmacology, National Institute of Mental Health, Saint Elizabeth's Hospital, Washington, DC 20032 and ${ }^{*}$ Food \\ and Drug Administration, Bureau of Drugs, Division of Drug Biology, Washington, DC 20204
}

\begin{abstract}
The solubilization and partial purification from rat brain cortex homogenates of $\left[{ }^{3} \mathrm{H}\right] \gamma$-aminobutyric acid (GABA) and $\left[{ }^{3} \mathrm{H}\right]$ diazepam recognition sites and of their endogenous modulators (GABAmodulin and an endogenous compound which displaces specifically bound $\left[{ }^{3} \mathrm{H}\right]$ diazepam) are reported.

A high percentage of GABA binding sites (virtually free of benzodiazepine binding sites) was solubilized from homogenates of rat brain cortex incubated at $0^{\circ} \mathrm{C}$ with $1 \%$ Triton $\mathrm{X}-100$ and a mixture of protease inhibitors. A large proportion of benzodiazepine binding sites was solubilized in the absence of apparent GABA binding capacity by incubating crude synaptic membrane preparations at $37^{\circ} \mathrm{C}$ with $0.05 \%$ Triton $\mathrm{X}-100$. The characteristics of these two solubilized binding sites resemble those of the membrane-bound binding sites. However, unlike the membrane-bound sites, solubilized GABA and benzodiazepine recognition sites have lost the ability to cross-react. Hence, solubilized benzodiazepine binding sites are insensitive to GABA stimulation, while solubilized $\mathrm{G} \Lambda \mathrm{B} \Lambda$ binding sites are no longer protected by the benzodiazepines against heat inactivation. These results indicate that $\mathrm{GABA}$ and benzodiazepine recognition sites reside in two different molecules which, when bound to membranes, can interact reciprocally and modulate their binding affinity for specific ligands.
\end{abstract}

The recognition sites for benzodiazepines and $\gamma$-aminobutyric acid (GABA) are located in the same postsynaptic membrane (Mohler et al., 1980a) and are coupled into a functional unit. In fact, GABA receptors function as a supramolecular entity, which includes the GABA recognition site, the benzodiazepine recognition site, and the $\mathrm{Cl}^{-}$ionophore, in addition to a number of other unidentified components (Guidotti et al., 1977; Costa and Guidotti, 1979; Baraldi et al., 1979; Tallman et al., 1978, 1980; Sieghart and Karobath, 1980). The benzodiazepine recognition site may be used physiologically by an endogenous agonist that participates in GABAergic transmission by modulating the affinity of the specific recognition sites for GABA (Guidotti et al., 1978; Skolnick et al., 1978; Asano and Spector, 1979; Colello et al., 1978; Davis and Cohen, 1980; Braestrup et al., 1980). Such a close functional association between GABA and benzodiazepine binding sites is underscored by recent histological evidence showing the presence of benzodiazepine recognition sites vis-à-vis axon terminals containing glutamic acid decarboxylase (Mohler et al., 1980b). This is in line with the observation made by Gavish and Snyder (1980) that GABA and benzodiazepine recognition sites can be solubilized as a functionally coupled unit. These results raise the question of whether GABA and benzodiazepine recognition sites are part of the same molecule or whether they are located in two distinct molecules functioning as an integral part of the same receptor. Since Gavish and Snyder (1980) solubilized only a portion of the membrane-bound GABA and benzodiazepine recognition sites, one might surmise that there are a number of functional arrangements for GABA and benzodiazepine receptors located in postsynaptic membranes and that the tight coupling is one of the ways in which these receptors are arranged. An understanding of this variability is crucial to define the molecular mechanisms whereby benzodiazepine recognition sites participate in the fine tuning of GABA receptors. The present paper shows that it is possible to solubilize a major portion of GABA and benzodiazepine recognition sites as separate molecular entities. In addition, evidence is presented showing that each of the two sites is regulated selectively by an endogenous modulator protein.

\section{Materials and Methods}

Male Sprague-Dawley rats, 200 to $250 \mathrm{gm}$, were sacrificed by guillotine and the brain was removed immediately. The cortices were dissected rapidly according to the method of Glowinski and Iversen (1966), placed on ice, and used as a source for the isolation and purification of $\left[{ }^{3} \mathrm{H}\right]$ benzodiazepine and $\left[{ }^{3} \mathrm{II}\right] \mathrm{GABA}$ recognition sites. 


\section{Solubilization of $\left[{ }^{3} H\right]$ benzodiazepine recognition sites}

'The starting material was frozen-thawed crude synaptic membranes (CSM) (Enna and Snyder, 1977), which were incubated at $0^{\circ} \mathrm{C}$ for $30 \mathrm{~min}$ in $20 \mathrm{vol}$ of $50 \mathrm{~mm}$ Tris/ citrate buffer, $\mathrm{pH} 7.1$, and then washed three times with the same buffer. This preparation was incubated at $37^{\circ} \mathrm{C}$ for $30 \mathrm{~min}$ in the presence of $0.05 \%$ Triton X-100. The suspension was then centrifuged at $10^{5} \times g$ for $1 \mathrm{hr}$ at $4^{\circ} \mathrm{C}$. Aliquots of $2 \mathrm{ml}$ of the supernatant were filtered rapidly on a Sephadex G-100 minicolumn $(2 \times 8 \mathrm{~cm})$ by centrifugation according to the method of Penefsky (1977). The recovery of $\left[{ }^{3} \mathrm{H}\right]$ diazepam binding sites throughout the column purification procedure was $75 \pm$ $9 \%(n=3)$. The purified supernatants were pooled and lyophilized, and the number of solubilized high affinity binding sites for $\left[{ }^{3} \mathrm{H}\right]$ benzodiazepines was measured.

\section{Solubilization of $\left[{ }^{3} H\right] G A B A$ recognition sites}

The cortices were homogenized with an Ultra Turrax homogenizer for $30 \mathrm{sec}$ in $20 \mathrm{vol}(\mathrm{w} / \mathrm{v})$ of $50 \mathrm{~mm}$ Tris/ citrate buffer, $\mathrm{pH} 7.1$, containing $1 \%$ Triton X-100 (3.6 $\mathrm{mg} / 10 \mathrm{mg}$ of tissue), $1 \mathrm{~mm}$ EGTA (ethylene glycol bis $(\beta$ aminoethyl ether)- $N, N, N^{\prime}, N^{\prime}$-tetra-acetic acid), $1 \% \beta$ mercaptoethanol, $100 \mathrm{BAEE}$ units/mg of protein of soybean trypsin inhibitor, $20 \mathrm{~mm} N$-ethylmaleimide, $0.3 \mathrm{~mm}$ $\mathrm{N}$-2-tosyl-1-lysin chloromethyl ketone. The homogenate was stirred at $4^{\circ} \mathrm{C}$ for $30 \mathrm{~min}$ and then centrifuged at $10^{5}$ $\times g$ for $1 \mathrm{hr}$ at $4^{\circ} \mathrm{C}$. Aliquots of $2 \mathrm{ml}$ of the $10^{5} \times g$ supernatant were filtered rapidly in succession, once on a Sephadex G-100 and twice on a Sephadex G-25 minicolumn $(2 \times 8 \mathrm{~cm})$, using the method of Penefsky (1977). In this supernatant, the recovery of $\left[{ }^{3} \mathrm{H}\right] \mathrm{GABA}$ binding sites was approximately $70 \%$. This purification procedure removes endogenous GABA, inhibitor of GABA binding, Triton X-100, protease inhibitors, and Tris/citrate. The final eluate, reconstituted in $50 \mathrm{~mm}$ Tris/citrate buffer, $\mathrm{pH} 7.1$, was used in the binding studies. In this sample, $\left[{ }^{3} \mathrm{H}\right] \mathrm{GABA}$ recognition sites were still in a soluble form because $(a)$ they were not precipitated by centrifugation at $200,000 \times g$ for $2 \mathrm{hr}$ and $(b)$ no binding of $\left[{ }^{3} \mathrm{H}\right]$ muscimol was detected if the sample was filtered through a 0.45 $\mu \mathrm{m}$ Millipore filter.

\section{Solubilization of GABA · benzodiazepine (BZD) recognition complex}

This complex was prepared according to the procedure described by Gavish and Snyder (1980). Frozen-thawed $\operatorname{CSM}(\mathrm{s})$ incubated at $0^{\circ} \mathrm{C}$ in $50 \mathrm{~mm}$ Tris/citrate buffer $(\mathrm{pH} \mathrm{7.1)}$ for $30 \mathrm{~min}$ and then washed three times with the same buffer was used as a starting material for the preparation of the receptor complex. The final suspension was incubated at $0^{\circ} \mathrm{C}$ for $30 \mathrm{~min}$ in the presence of $1 \%$ Triton X-100 and then centrifuged at $10^{5} \times g$ for $1 \mathrm{hr}$. The supernatant was filtered by the rapid centrifugation method of Penefsky (1977) on a Sephadex G-100 column $(2 \times 8 \mathrm{~cm})$. The resulting supernatant, which was termed "solubilized GABA-BZD recognition complex," was used in the binding studies.

\section{Extraction of "GABA-modulin" and of the endogenous inhibitor of specific $\left[{ }^{3} \mathrm{H}\right]$ benzodiazepine recognition sites}

Frozen/thawed CSM(s) from cortex of rat brain was used as the starting material. Endogenous GABA and other amino acids that inhibit $\left[{ }^{3} \mathrm{H}\right] \mathrm{GABA}$ binding were removed by incubating the $\mathrm{CSM}(\mathrm{s})$ at $37^{\circ} \mathrm{C}$ for $30 \mathrm{~min}$ in the presence of $0.05 \%$ Triton X-100 $(0.18 \mathrm{mg} / \mathrm{mg}$ of membrane protein) and then washing the $\operatorname{CSM}(\mathrm{s})$ three times with $50 \mathrm{~mm}$ Tris/citrate buffer, $\mathrm{pH} 7.1$ (Massotti and Guidotti, 1980). GABA-modulin and the endogenous inhibitor of benzodiazepine binding were extracted by homogenizing these membranes in $\mathrm{H}_{2} \mathrm{O}$ ( $1 \mathrm{mg}$ of protein/ $\mathrm{ml}$ of $\mathrm{H}_{2} \mathrm{O}$ ) containing $0.05 \%$ Triton $\mathrm{X}-100$. The suspension was incubated at $0^{\circ} \mathrm{C}$ for $30 \mathrm{~min}$, sonicated for 30 sec, and then centrifuged at $10^{5} \times g$ for $60 \mathrm{~min}$. The operation was repeated a second time. The two $10^{5} \times g$ supernatants were lyophilized and, after reconstitution in $\mathrm{H}_{2} \mathrm{O}$, were termed "extract $\mathrm{A}$ " and used as a source for the preparation of either of the two inhibitors. Typically with this procedure, $12 \mu \mathrm{g}$ of protein inhibitors are extracted from $1 \mathrm{mg}$ of membrane proteins.

The inhibitor of $\left[{ }^{3} \mathrm{H}\right]$ benzodiazepine binding was isolated by incubating "extract $\mathrm{A}$ " for $15 \mathrm{~min}$ at $95^{\circ} \mathrm{C}$ and by chromatographing the $10^{5} \times g$ supernatant $(20 \mathrm{~min})$ with a Bio-Gel P-2 column $(1 \times 80 \mathrm{~cm})$ and then with a Sephadex G-100 $(1 \times 80 \mathrm{~cm})$ column equilibrated with 10 mM Tris/citrate buffer, $\mathrm{pH}$ 7.1.

GABA-modulin was isolated from the $10^{5} \times g$ supernatant of fresh "extract A." One milliliter of this supernatant contained approximately $2.5 \mathrm{mg}$ of protein, $2 \mathrm{mg}$ of phospholipids, and $5 \mathrm{pmol}$ of GABA. The sample was filtered five times by centrifugation on Bio-Gel P-2 $(2 \times$ $8 \mathrm{~cm}$ ) (Mazzari et al., 1980) and then applied to a Sephadex G-50 column $(1 \times 80 \mathrm{~cm})$ equilibrated with Tris/ citrate buffer, $\mathrm{pH} 7.1$.

\section{Determination of $G A B A$}

The GABA content of various preparations was determined using high pressure liquid chromatography (HPLC). After $0.2 \mathrm{~N}$ perchloric acid extraction, the samples were processed according to Schmid et al. (1980). GABA also was determined according to Bertilsson and Costa (1976) by ion monitoring ( $m / e 233$ and 394) using a LKB 9000 gas chromatograph and mass spectrometer (GC-MS). The sensitivity was approximately $10 \mathrm{pmol}$ for HPLC and 5 pmol for GC-MS.

\section{Determination of phospholipids}

The sample was extracted with 5 vol of chloroform/ methanol (2:1 by volume) according to Folch et al. (1957). The presence of phospholipids was examined on Silica Gel $\mathrm{G}$ thin layer chromatography using the method of Skipski and Barclay (1969). After developing, the plates were dried and the phospholipids were visualized by exposure to iodine.

\section{Studies on the thermolability of $\left[{ }^{3} H\right] G A B A$ recognition sites}

Suspensions of solubilized (300 to $400 \mu \mathrm{g}$ of protein/ $\mathrm{ml}$ ) or membrane-bound ( 800 to $1000 \mu \mathrm{g}$ of protein $/ \mathrm{ml}$ ) recognition sites for $\left[{ }^{3} \mathrm{H}\right] \mathrm{GABA}$ were preincubated at $4^{\circ} \mathrm{C}$ with $10^{-5}$ M GABA (15 min), $10^{-6}$ M diazepam, or other benzodiazepines $(1 \mathrm{hr})$. After incubation at $60^{\circ} \mathrm{C}$ for $1,3,6,9,12$, and $24 \mathrm{~min}$, the suspensions were cooled on ice.

In order to remove the GABA or the benzodiazepines from the solubilized recognition sites, these suspensions 
were filtered twice by centrifugation (Penefsky, 1977) on a Sephadex G-25 gel minicolumn.

To remove GABA or benzodiazepines from the membranes, the suspensions were centrifuged at $48,000 \times g$ for $10 \mathrm{~min}$ and the pellets were washed twice with a double volume of $50 \mathrm{~mm}$ Tris buffer, $\mathrm{pH}$ 7.1.

\section{Binding assay of $\left[{ }^{3} H\right] G A B A,\left[{ }^{3} H\right] m u s c i m o l$, and $\left[{ }^{3} \mathrm{H}\right]$ diazepam}

The following procedures were used to assay the high affinity binding of the different ${ }^{3} \mathrm{H}$ ligands to soluble or membrane-bound specific recognition sites.

Solubilized GABA recognition sites. The reaction was initiated by adding $20 \mu \mathrm{l}$ of the various $\left[{ }^{3} \mathrm{H}\right] \mathrm{GABA}$ or $\left[{ }^{3} \mathrm{H}\right]$ muscimol solutions (to reach a final concentration of 0.3 to $240 \mathrm{nM}$ in a total volume of $200 \mu \mathrm{l}$ ) to a test tube containing solubilized recognition sites (40 to $60 \mu \mathrm{g}$ of protein). After $5 \mathrm{~min}$ of incubation at $0^{\circ} \mathrm{C}$, the reaction was terminated by applying $50 \mu$ l of the incubation mixture on a minicolumn $(0.5 \times 6 \mathrm{~cm})$ of Sephadex G-25 kept at $0^{\circ} \mathrm{C}$. Bound $\left[{ }^{3} \mathrm{H}\right] \mathrm{GABA}$ was separated from the free $\left[{ }^{3} \mathrm{H}\right]$ GABA by centrifuging the minicolumn at $1000 \mathrm{rpm}$ for $2.5 \mathrm{~min}$ (Penefsky, 1977). The radioactivity present in the first $50 \mu \mathrm{l}$ of filtrate corresponded to the amount bound to the receptor. In the absence of protein, less than $0.5 \%$ of the radioactivity emerged in the void volume. Specific binding was calculated as the difference between the total binding and the binding that occurred in the presence of $1 \mathrm{mM}$ GABA or $1 \mu \mathrm{M}$ muscimol.

Solubilized benzodiazepine recognition sites. The reaction was initiated by adding $20 \mu \mathrm{l}$ of the various $\left[{ }^{3} \mathrm{H}\right]$ diazepam solutions (to reach final concentrations of 0.3 to $48 \mathrm{nM}$ in a total volume of $200 \mu \mathrm{l}$ ) to a test tube containing 40 to $60 \mu \mathrm{g}$ of solubilized proteins. After $1 \mathrm{hr}$ of incubation at $0^{\circ} \mathrm{C}$, the reaction was terminated by adding $200 \mu \mathrm{l}$ of $0.1 \% \gamma$-globulin and $200 \mu \mathrm{l}$ of $24 \%$ polyethylene glycol to precipitate the solubilized receptors as described by Yousufi et al. (1979). The suspension was filtered immediately under a vacuum on a $\mathrm{GF} / \mathrm{B}$ filter. The filter was washed with $9 \mathrm{ml}$ of $50 \mathrm{~mm}$ Tris/citrate buffer, $\mathrm{pH} 7.1$, containing $8 \%$ polyethylene glycol. In some experiments, the results obtained with the method of Yousufi et al. (1979) were repeated by terminating the reaction by filtration of the suspension on a Sephadex $G$ 25 column $(0.5 \times 6 \mathrm{~cm})$ according to Penefsky (1977). No significant difference in the number of specific binding sites was found between the two methods used to terminate the reaction. Specific binding was calculated as the difference between the total binding and the binding that occurred in the presence of $10^{-6} \mathrm{M}$ diazepam or clonazepam.

Solubilized GABA.BZD recognition complex. $\left[{ }^{3} \mathrm{H}\right]-$ GABA or $\left[{ }^{3} \mathrm{H}\right]$ diazepam binding assays were performed as previously reported for the solubilized receptors.

Binding of $\left[{ }^{3} \mathrm{H}\right] \mathrm{GABA},\left[{ }^{3} \mathrm{H}\right] \mathrm{muscimol}$, or $\left[{ }^{3} \mathrm{H}\right]$ diazepam to the membrane-bound receptors. This binding was carried out with minor modifications of the method previously described (Baraldi et al., 1979).

\section{Statistical analysis}

The characteristics of $\left[{ }^{3} \mathrm{H}\right] \mathrm{GABA}$ and $\left[{ }^{3} \mathrm{H}\right]$ diazepam binding were determined by using a Scatchard plot analysis of the saturation curves. Specifically, the Scatchard plots of the $\left[{ }^{3} \mathrm{H}\right] \mathrm{GABA}$ binding data were prepared ac- cording to the graphic method of Rosenthal (1967) to determine the binding parameters (number of equivalent binding sites and the corresponding dissociation constants) in a complex system consisting of one ligand and two or more populations of binding sites. In each experiment, the values of the $K_{D}$ and $B_{\max }$ were between 5 and $10 \%$ of the mean $K_{D}$ and $B_{\max }$ values. The statistical significance of the results was determined by the Students $t$ test (two tailed). Unbiased estimates of the standard error of the mean were computed and the means were compared as unpaired observations with equal variance.

\section{Protein assay}

The protein concentration was measured by the method of Lowry et al. (1951).

\section{Results}

Characterization of the endogenous modulator of $\left[{ }^{3} H\right] G A B A$ and $\left[{ }^{3} H\right]$ diazepam binding. The inhibitor of $\left[{ }^{3} \mathrm{H}\right] \mathrm{GABA}$ binding used in these experiments was isolated by Bio-Gel P-2 and Sephadex G-50 chromatography (see "Materials and Methods"). After Sephadex G-50, one major peak of inhibitory activity was obtained and this peak was eluted by a buffer volume similar to that of ribonuclease A. No significant inhibitory activity of $\left.{ }^{3} \mathrm{H}\right] \mathrm{GABA}$ binding was eluted in the position in which $\left[{ }^{3} \mathrm{H}\right] \mathrm{GABA}$ emerged. In a typical preparation, $100 \mu \mathrm{l}$ of inhibitory peak (containing $10 \mu \mathrm{g}$ of protein) produced a $50 \%$ inhibition of $\left[{ }^{3} \mathrm{H}\right] \mathrm{GABA}$ binding. The characteristics of this inhibitor (GABA-modulin) are summarized in Table I.

A preliminary purification of the endogenous inhibitor of $\left[{ }^{3} \mathrm{H}\right]$ diazepam binding was carried out by Bio-Gel P-2 column chromatography of a heat-treated brain extract (see "Materials and Methods"). This inhibitor emerged from this column with the void volume (see Fig. 1, upper). When the effluent from the Bio-Gel P-2 column that contained this inhibitor was chromatographed with a Sephadex G-100 column, the major peak of inhibition emerged after the void volume and before ovalbumin (Fig. 1, lower). The characteristics of the material endowed with the capacity to inhibit $\left[{ }^{3} \mathrm{H}\right]$ diazepam binding are summarized in Table I.

Solubilized preparation of benzodiazepine binding sites. The recognition sites for $\left[{ }^{3} \mathrm{H}\right]$ benzodiazepines which are located on CSM can be solubilized free from $\left[{ }^{3} \mathrm{H}\right] \mathrm{GABA}$ binding capacity by treating frozen-thawed CSM (see "Materials and Methods") with $0.05 \%$ Triton $\mathrm{X}-100$ at $37^{\circ} \mathrm{C}$ for $30 \mathrm{~min}$. When this procedure is repeated three times and each time is followed by a CSM washing with Tris buffer, the number of $\left[{ }^{3} \mathrm{H}\right]$ diazepam recognition sites that remain bound to the CSM decreases. In contrast, there is no apparent decrease in the number of $\mathrm{Na}^{+}$-independent, high or low affinity recognition sites for $\left[{ }^{3} \mathrm{H}\right]$ GABA (see Table II). After each treatment, the decrease in the number of $\left[{ }^{3} \mathrm{H}\right]$ benzodiazepine binding sites located in CSM was paralleled by the appearance of an almost equal number of $\left[{ }^{3} \mathrm{H}\right]$ benzodiazepine recognition sites in the $10^{5} \times g$ supernatant (Table III). The solubilization of $\left[{ }^{3} \mathrm{H}\right]$ benzodiazepine binding sites occurred during the first and second incubation of the CSM with $0.05 \%$ Triton X-100; the third 
TABLE I

Characteristics of membrane-bound molecules that interfere with binding of $\left[^{3} \mathrm{H}\right] \mathrm{GABA}$ and $\left[{ }^{3} \mathrm{H}\right]$ diazepam

The characteristics of GABA-modulin were: (1) GABA-modulin elution pattern from a G-50 or G-100 column was similar to that of ribonuclease A (a marker of $M_{\mathrm{r}}=14,000$ ). (2) When the supernatant of extract A (see "Materials and Methods" for details) was heat treated $\left(95^{\circ} \mathrm{C}\right.$ for $\left.15 \mathrm{~min}\right)$, the inhibitory activity eluted from the Sephadex G50 column was reduced by approximately $70 \%$. ( 3 and 4 ) When GABAmodulin preparations were incubated at $37^{\circ} \mathrm{C}$ for $4 \mathrm{hr}$ in the presence of pronase or trypsin $(100 \mu \mathrm{g} / \mathrm{ml})$, their inhibitory activity decreased and the activity present was due to inhibitory material of small molecular weight (500 to 800 ). (5 and 7) GABA-modulin inhibited noncompetitively the binding of GABA to high affinity sites located on Triton $\mathrm{X}$-100-treated CSM(s); GABA-modulin failed to change the $\left[{ }^{3} \mathrm{H}\right] \mathrm{GABA}$ binding to low affinity sites located on the same membranes (see also Toffano et al., 1978). ( 6 and 8 ) GABA-modulin did not inhibit $\left[{ }^{3} \mathrm{H}\right]$ diazepam binding when tested on Triton X-100-treated CSM (Table V). However, GABA-modulin (up to $25 \mu \mathrm{g}$ of protein) inhibited the GABA-induced $\left(10^{-7} \mathrm{M}\right)$ stimulation of $\left[{ }^{3} \mathrm{H}\right]$ diazepam (1.5 nM) binding in proportion to the amount of GABA-modulin added. ( 9 and 10) When a preparation of GABA-modulin $(100 \mu \mathrm{g}$ of protein in $1 \mathrm{ml})$ was incubated with $20 \mathrm{pmol}$ of $\left[{ }^{3} \mathrm{H}\right] \mathrm{GABA}$ or 6 pmol of $\left[{ }^{3} \mathrm{H}\right]$ diazepam and then the mixture was applied to a Sephadex G-25 minicolumn (Penefsky, 1977), more than $99.9 \%$ of the label was eluted without the GABAmodulin. (11) GABA-modulin can be precipitated almost completely by treating the preparation with ammonium sulfate (30 to $60 \%$ ). The protein that precipitated with less than $30 \%$ or more than $60 \%$ ammonium sulfate failed to show inhibitory activity. (12) In a GABA-modulin preparation containing $100 \mu \mathrm{g}$ of protein, the phospholipid content extracted with chloroform/methanol is undetectable $(<25 \mu \mathrm{g})$. (13) The GABA content in a GABA-modulin preparation containing $100 \mu \mathrm{g}$ of protein was below the sensitivity of our HPLC or GC-MS method (5 pmol for GC-MS and $10 \mathrm{pmol}$ for HPLC). In addition, formic acid extracts of this GABA-modulin preparation failed to inhibit $\left[{ }^{3} \mathrm{H}\right] \mathrm{GABA}$ binding. (14) GABA-modulin preparations $(20 \mu \mathrm{g}$ of protein in $100 \mu \mathrm{l})$ or GABA ( $1 \mathrm{nmol}$ in $100 \mu \mathrm{l})$ were incubated at $26^{\circ} \mathrm{C}$ for $50 \mathrm{~min}$ with GABASE ( 0.05 unit) in a medium identical to that used for the assay of GABA in tissue extracts (Okada et al., 1971). In the presence of heatinactivated GABASE, GABA-modulin produced a $75 \%$ and GABA a $96 \%$ inhibition of specifically bound $\left[{ }^{3} \mathrm{H}\right] \mathrm{GABA}$, respectively $(4064 \mathrm{cpm}$, control; $1456 \mathrm{cpm}$, GABA-modulin; and $200 \mathrm{cpm}, \mathrm{GABA})$. When the same samples were incubated in the presence of active GABASE, the amount of [ $\left.{ }^{3} \mathrm{H}\right] \mathrm{GABA}$ binding was $2058 \mathrm{cpm}$ and $4130 \mathrm{cpm}$ for GABAmodulin and GABA, respectively. (15) GABA-modulin preparations dialyzed $12 \mathrm{hr}$ at $0^{\circ} \mathrm{C}$ versus $4000 \mathrm{vol}$ of Tris buffer lose only $20 \%$ of their original inhibitory activity.

incubation failed to solubilize additional $\left[{ }^{3} \mathrm{H}\right]$ diazepam binding sites (Table II). As shown in Tables II and III, two Triton X-100 washes solubilized more than $50 \%$ of the $\left[{ }^{3} \mathrm{H}\right]$ benzodiazepine binding sites, while they failed to extract the high or the low affinity binding sites for $\left[{ }^{3} \mathrm{H}\right] \mathrm{GABA}$. The absence of apparent GABA binding sites was not due to the presence of contaminating GABA in the solubilized preparation because the content of GABA measured by HPLC and GC-MS techniques was below 1 pmol/assay tube (see also Table III). Higher concentrations (up to $2 \%$ ) of Triton X-100, Lubrol $(0.5 \%, 2 \mathrm{mg} / \mathrm{mg}$ of protein), or deoxycholate $(2 \%, 10 \mathrm{mg} / \mathrm{mg}$ of protein) failed to solubilize the $\left[{ }^{3} \mathrm{H}\right]$ benzodiazepine binding sites that remained bound to CSM after two $0.05 \%$ Triton X100 treatments. However, each of these treatments produced the solubilization of a significant amount of GABA binding sites. When the solubilized material was applied to a Sephadex G-100 column $(1 \times 80 \mathrm{~cm})$, approximately $90 \%$ of the solubilized recognition sites for $\left[{ }^{3} \mathrm{H}\right]$ benzodiazepine emerged from the column with the bulk of the
The characteristics of $\left[{ }^{3} \mathrm{H}\right]$ diazepam binding inhibition (DBI) were as follows: (1) The molecular weight of DBI was greater than 1800 (it emerged with the void volume from a Bio-Gel P-2 column) and smaller than 100,000 (it emerged after the void volume in a Sephadex G-100 column) (Fig. 1). (2) DBI was stable (100\%) after treatment at $95^{\circ} \mathrm{C}$ for $15 \mathrm{~min}$. (4) Pronase $\left(100 \mu \mathrm{g} / \mathrm{ml}\right.$ for $2 \mathrm{hr}$ at $37^{\circ} \mathrm{C}$ destroyed approximately $50 \%$ of DBI activity (Massotti et al., 1980). (5) DBI failed to inhibit the high affinity $\left[{ }^{3} \mathrm{H}\right] \mathrm{GABA}$ binding (see also Table V). (6) DBI inhibited competitively the binding of $\left[{ }^{3} \mathrm{H}\right]$ diazepam to high affinity sites located on Triton X-100-treated CSM (Fig. 2). (9 and 10) In an experimental condition similar to that used for GABA-modulin, DBI (up to $200 \mu \mathrm{g}$ of protein) bound less than $0.2 \%$ of $\left[{ }^{3} \mathrm{H}\right]$ diazepam or $\left[{ }^{3} \mathrm{H}\right] \mathrm{GABA}$. (15) Samples of the inhibitor dialyzed for $24 \mathrm{hr}$ versus $4000 \mathrm{vol}$ of Tris buffer lost less than $10 \%$ of its original inhibitory activity.

\begin{tabular}{|c|c|c|}
\hline Characteristics & GABA-modulin $^{\alpha}$ & $\begin{array}{l}\text { Endogenous In- } \\
\text { hibitor of }\left[{ }^{3} \mathrm{H}\right] \mathrm{Di}- \\
\text { azepam Binding }\end{array}$ \\
\hline 1. Molecular weight & $\sim 15,000$ & $>1,800$ \\
\hline 2. Thermostability & No & Yes \\
\hline 3. Tryptic digestion & Yes & $-c$ \\
\hline 4. Pronase digestion & Yes & Yes \\
\hline $\begin{array}{l}\text { 5. Inhibition of }\left[{ }^{3} \mathrm{H}\right] \mathrm{GABA} \\
\text { binding }\end{array}$ & Yes & No \\
\hline $\begin{array}{l}\text { 6. Inhibition of }\left[{ }^{3} \mathrm{H}\right] \text { diazepam } \\
\text { binding }\end{array}$ & No & Yes \\
\hline 7. Mechanism of inhibition & Noncompetitive & Competitive \\
\hline $\begin{array}{l}\text { 8. Inhibition of GABA-stim- } \\
\text { ulated }\left[{ }^{3} \mathrm{H}\right] \text { diazepam } \\
\text { binding }\end{array}$ & Yes & - \\
\hline 9. Binds $\left[{ }^{3} \mathrm{H}\right] \mathrm{GABA}$ & No & No \\
\hline 10. Binds $\left[{ }^{3} \mathrm{H}\right]$ diazepam & No & No \\
\hline $\begin{array}{l}\text { 11. Precipitated by } 30 \text { to } 60 \% \\
\text { ammonium sulfate }\end{array}$ & Yes & No \\
\hline 12. Phospholipid content & $<25 \mu \mathrm{g} / 100 \mu \mathrm{l}$ & - \\
\hline 13. GABA content & $<1 \mathrm{pmol} / 100 \mu \mathrm{l}$ & - \\
\hline 14. GABASE resistant & Yes & - \\
\hline 15. Dialyzable & No & No \\
\hline
\end{tabular}

${ }^{a}$ In the assay, $100 \mu \mathrm{l}$ of GABA-modulin containing $10 \mu \mathrm{g}$ of protein was used.

${ }^{b}$ In the assay, $100 \mu \mathrm{l}$ of inhibitor of $\left[{ }^{3} \mathrm{H}\right]$ diazepam binding containing $50 \mu \mathrm{g}$ of protein was used.

- , not tested.

proteins. This preliminary finding suggested to us that a filtration of the solubilized binding sites through a Sephadex G-100 minicolumn (see "Materials and Methods") could give us a rapid and partial purification useful for measuring the density and other characteristics of $\left[{ }^{3} \mathrm{H}\right]$ benzodiazepine binding sites.

The solubilized and partially purified $\left[{ }^{3} \mathrm{H}\right]$ benzodiazepine binding sites bind $\left[{ }^{3} \mathrm{H}\right]$ diazepam with a $K_{D}$ of approximately $2.0 \mathrm{~nm}$ and a $B_{\max }$ of about $5.8 \mathrm{pmol} / \mathrm{mg}$ of protein (Fig. 3), whereas these recognition sites, when they are bound to the membrane, like those that cannot be solubilized, have a $K_{D}$ of $8 \mathrm{nM}$ and a $B_{\max }$ of $1.4 \mathrm{pmol} /$ $\mathrm{mg}$ of protein. The solubilized binding sites are saturable (Fig. 3), stereospecific (Fig. 4), and have a Hill coefficient of 0.92 . Moreover, the $\left[{ }^{3} \mathrm{H}\right]$ diazepam bound to solubilized recognition sites was displaced by various benzodiazepines with a rank order of potency similar to that displayed for $\left[{ }^{3} \mathrm{H}\right]$ diazepam bound to recognition sites located on CSM (see Fig. 4). The only exception was flunitrazepam which was more potent in displacing 


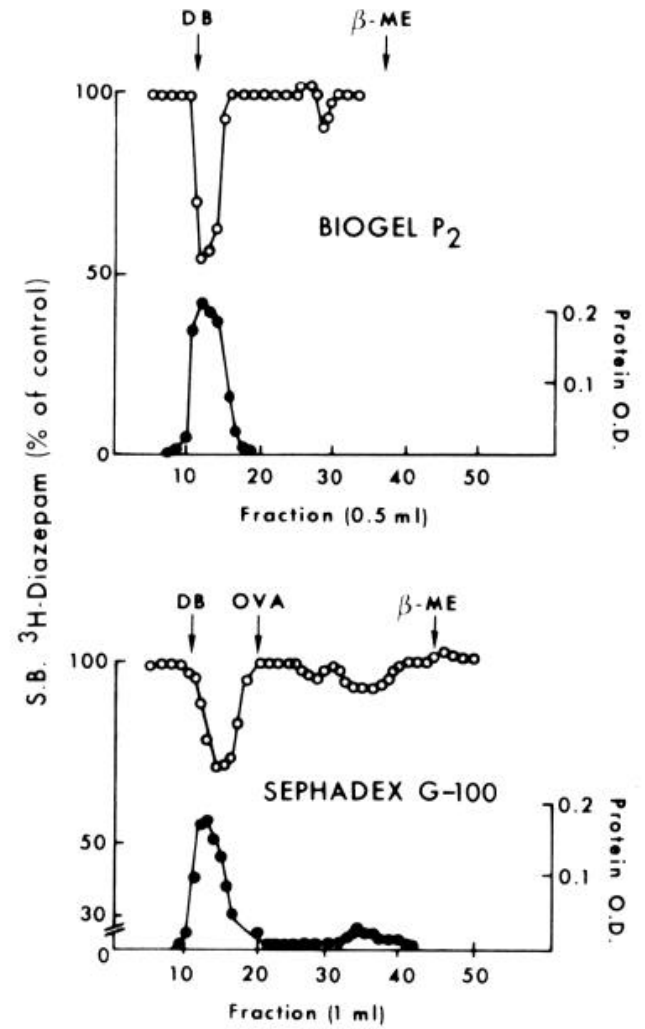

Figure 1. Bio-Gel P-2 and Sephadex G-100 chromatography of the endogenous ligand of $\left[{ }^{3} \mathrm{H}\right]$ diazepam binding. The inhibitor was extracted from rat brain cortex as described under "Materials and Methods." Two milligrams of protein was applied to the Bio-Gel P-2 column. Fractions 11 to 18 were pooled, together lyophilized and resuspended in $1 \mathrm{ml}$ of $50 \mathrm{~mm}$ Tris/ citrate, and applied to the Sephadex G-100 column equilibrated with the same buffer and $100 \mathrm{~mm} \mathrm{NaCl}$. Two hundred microliters of each fraction was used to measure the inhibitory activity of $\left[{ }^{3} \mathrm{H}\right]$ diazepam $(1.5 \mathrm{nM})$ binding. Blue Dextran $(D B)$, ovalbu$\min (O V A)$, and $\beta$-mercaptoethanol $(\beta M E)$ were used as markers of the elution volume. S.B., specifically bound; O.D., optical density.

$\left[{ }^{3} \mathrm{H}\right]$ diazepam from solubilized than from membranebound recognition sites (Fig. 4). Table IV shows that the binding of $\left[{ }^{3} \mathrm{H}\right]$ diazepam to solubilized recognition sites is no longer increased by the addition of GABA nor blocked by the addition of $10^{-4} \mathrm{M}$ bicuculline. This finding contrasts with the GABA-induced stimulation of $\left[{ }^{3} \mathrm{H}\right]-$ benzodiazepine binding to membrane-bound recognition sites or to solubilized GABA.BZD recognition complex (see Table IV). The endogenous compound that inhibits $\left[{ }^{3} \mathrm{H}\right]$ diazepam binding to specific recognition sites is equally potent in inhibiting the binding of $\left[{ }^{3} \mathrm{H}\right]$ benzodiazepines to membrane-bound recognition sites, to solubilized recognition sites complexed with GABA recognition sites, or to recognition sites that are solubilized without GABA binding sites (Table V). The solubilized $\left[{ }^{3} \mathrm{H}\right]$ diazepam binding sites are less stable than those that are membrane bound. They have a half-life of 2 days when the solution containing $\left[{ }^{3} \mathrm{H}\right]$ diazepam solubilized recognition sites is kept at 0 to $4^{\circ} \mathrm{C}$.

Preparation of solubilized $\left[{ }^{3} \mathrm{H}\right] \mathrm{GABA}$ recognition sites. $\left[{ }^{3} \mathrm{H}\right] \mathrm{GABA}$ recognition sites were purified and solubilized using as a starting material a homogenate of rat brain cortex. The $\left[{ }^{3} \mathrm{H}\right] \mathrm{GABA}$ recognition sites were sol- ubilized by homogenizing the tissue in a solution containing $1 \%$ Triton X-100 and a number of protease inhibitors (see "Materials and Methods"). The final concentration of GABA in this homogenate was about $5 \times 10^{-5} \mathrm{M}$.

This extraction procedure solubilizes $72 \%$ of the GABA binding sites but only $8 \%$ of the benzodiazepine binding sites (see Table VI). Concentrations of Triton X-100 higher than $1 \%$ failed to increase the extent of GABA binding site solubilization. Scatchard analysis of the

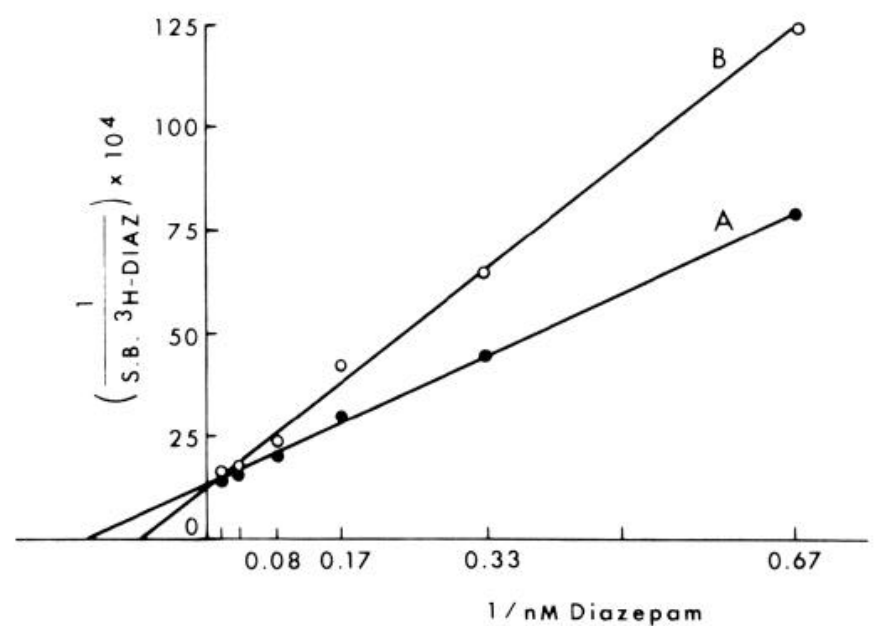

Figure 2. Lineweaver-Burk plot of $\left[{ }^{3} \mathrm{H}\right]$ diazepam binding to crude synaptic membranes in the absence $(A)$ and presence $(B)$ of the endogenous ligand for benzodiazepines. The assay was carried out in membranes washed three times with Triton X100 (see "Materials and Methods" for details). The membranes were preincubated $1 \mathrm{hr}$ at $0^{\circ} \mathrm{C}$ with Tris $(A)$ or with $50 \mu \mathrm{g}$ of protein fraction containing the inhibitor $(B)$. The apparent dissociation constant $\left(K_{D}\right)$ is $6.5 \mathrm{nM}$ in $A$ and $12 \mathrm{nM}$ in B. S.B., specifically bound.

\section{TABLE II}

Effect of $0.05 \%$ Triton X-100 treatment on the maximal density of $\left[{ }^{3} \mathrm{H}\right] \mathrm{GABA}$ and $\left[{ }^{3} \mathrm{H}\right]$ diazepam binding sites in CSM prepared from rat brain cortex

Frozen-thawed CSM(s) prepared according to Gavish and Snyder (1980) were incubated at $37^{\circ} \mathrm{C}$ for $30 \mathrm{~min}$ in the absence (none) or presence of $0.05 \%$ Triton X-100 $(0.18 \mathrm{mg} / \mathrm{mg}$ of protein) (1st Triton) and then washed twice with $50 \mathrm{~mm}$ Tris/citrate buffer, $\mathrm{pH}$ 7.1. Aliquots (300 to $400 \mu \mathrm{g}$ of protein) were used for the assay. The residual aliquot was stored at $-20^{\circ} \mathrm{C}$ for $12 \mathrm{hr}$. On these membranes, incubation at $37^{\circ} \mathrm{C}$ for $30 \mathrm{~min}$ in the presence of Triton X-100 was repeated a second (2nd Triton) and a third (3rd Triton) time. Each value is the mean \pm SEM of at least five experiments performed in triplicate.

\begin{tabular}{|c|c|c|c|}
\hline \multirow{3}{*}{$\begin{array}{l}\text { Membrane } \\
\text { Treatment }\end{array}$} & \multicolumn{3}{|c|}{$B_{\max }$} \\
\hline & \multicolumn{2}{|c|}{ S.B. ${ }^{a}\left[{ }^{3} \mathrm{H}\right] \mathrm{GABA}$} & \multirow{2}{*}{$\begin{array}{l}\text { S.B. }\left[{ }^{3} \mathrm{H}\right] \text { Diazepam } \\
\text { High Affinity }\end{array}$} \\
\hline & High Affinity & Low Affinity & \\
\hline & \multicolumn{3}{|c|}{ pmol/gm tissue } \\
\hline None & $25 \pm 2$ & $190 \pm 21$ & $160 \pm 11$ \\
\hline 1st Triton & $37 \pm 2^{b}$ & $200 \pm 18$ & $110 \pm 14^{c}$ \\
\hline 2nd Triton & $55 \pm 4^{c}$ & $212 \pm 10$ & $67 \pm 4^{c}$ \\
\hline 3rd Triton & $90 \pm 5^{c}$ & $225 \pm 22$ & $60 \pm 6^{c}$ \\
\hline
\end{tabular}

${ }^{a}$ S.B., specifically bound.

${ }^{b} p<0.05$ when compared with the control group (none) according to the Student's $t$ test,

${ }^{c} p<0.01$ when compared with the control group (none) according to the Student's $t$ test. 
TABLE III

Selective solubilization of benzodiazepine recognition sites from CSM

Pooled $10^{5} \times g$ supernatants (200 to $300 \mu \mathrm{g}$ of protein/ml) and final pellets (400 to $600 \mu \mathrm{g}$ of protein/ml) from crude synaptic membranes treated twice at $37^{\circ} \mathrm{C}$ for $30 \mathrm{~min}$ with $(0.05 \%$ Triton $\mathrm{X}-100)$ or without (none) Triton $\mathrm{X}-100$ were used for $\left[{ }^{3} \mathrm{H}\right]$ muscimol $(10 \mathrm{~nm})$ and $\left[{ }^{3} \mathrm{H}\right]$ diazepam $(24 \mathrm{~nm})$ binding assay. Each value is the mean \pm SEM of three experiments performed in triplicate. The specific activity of $\left[{ }^{3} \mathrm{H}\right] \mathrm{muscimol}$ and $\left[{ }^{3} \mathrm{H}\right]$ diazepam bound to the solubilized recognition site was calculated based on the content of membrane proteins. The values of the pooled supernatants were not corrected for the loss (see "Materials and Methods") encountered during the G-100 and/or G-25 chromatography purification procedure. The content of GABA in the solubilized preparation was less than 1 pmol/assay tube.

\begin{tabular}{|c|c|c|c|c|c|c|}
\hline \multirow{3}{*}{ Treatment } & \multicolumn{3}{|c|}{ S.B. ${ }^{a}\left[{ }^{3} \mathrm{H}\right]$ Muscimol } & \multicolumn{3}{|c|}{ S.B. $\left[{ }^{3} \mathrm{H}\right]$ Diazepam } \\
\hline & Residual Pellet & \multicolumn{2}{|c|}{ Pooled Supernatants } & Residual Pellet & \multicolumn{2}{|c|}{ Pooled Supernatants } \\
\hline & \multicolumn{2}{|c|}{$\mathrm{pmol} / \mathrm{mg}$ protein } & $\%$ solub. & \multicolumn{2}{|c|}{$\mathrm{pmol} / \mathrm{mg}$ protein } & \% solub. \\
\hline $0.05 \%$ Triton $\mathrm{X}-100(\times 2)$ & $6.5 \pm 0.4$ & $0.2 \pm 0.3$ & 0.3 & $1.4 \pm 0.10^{c}$ & $1.5 \pm 0.08^{c}$ & 51 \\
\hline
\end{tabular}

"S.B., specifically bound.

${ }^{b}$ nd, not determined.

$p<0.01$ when compared with control (none) according to the Student's $t$ test.
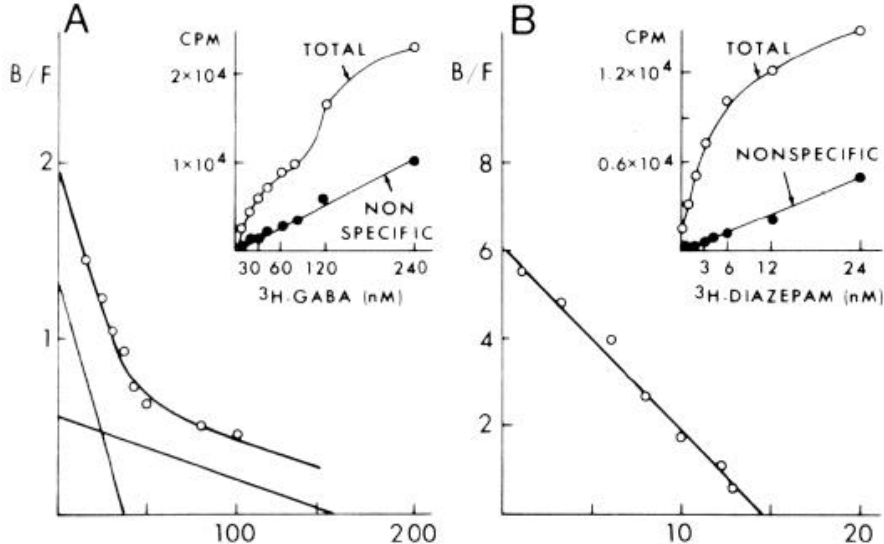

SPECIFICALLY BOUND ${ }^{3} \mathrm{H}$.LIGAND (pmoles/g cortex)

Figure 3. Binding of $\left[{ }^{3} \mathrm{H}\right] \mathrm{GABA}$ (panel $A$ ) and $\left[{ }^{3} \mathrm{H}\right]$ diazepam ( panel $B$ ) to solubilized and partially purified GABA and diazepam recognition sites. The saturation curves (shown in the insets) were analyzed by Scatchard plot and Rosenthal (Rosenthal, 1967) plot analysis. The values represent the mean of three separate experiments. $B / F$, bound/free.

saturation curve for $\left[{ }^{3} \mathrm{H}\right] \mathrm{GABA}$ binding to solubilized GABA recognition sites revealed two apparent binding sites for GABA (see Fig. 3). The $K_{D}$ of these two binding sites were similar to those described for $\left[{ }^{3} \mathrm{H}\right] \mathrm{GABA}$ recognition sites located in CSM (Enna and Snyder 1977; Toffano et al., 1978). The binding of $\left[{ }^{3} \mathrm{H}\right] \mathrm{GABA}$ to solubilized recognition sites had the following characteristics:

1. It was inhibited by bicuculline with an $\mathrm{IC}_{50}$ of approximately $5 \times 10^{-5} \mathbf{M}$.

2. It was inhibited by GABA-modulin with a potency similar to that observed in CSM or in solubilized GABA.BZD recognition complex (Table V).

3. The thermoinactivation characteristics of solubilized $\left[{ }^{3} \mathrm{H}\right] \mathrm{GABA}$ binding sites were identical to those of the recognition sites bound to CSM (see Fig. 5).

4. The rate of heat $\left(60^{\circ} \mathrm{C}\right)$ inactivation of the solubilized GABA recognition sites was reduced when $10^{-5}$ M GABA was present in the incubation mixture (Fig. 5).

5. Diazepam, as well as other active benzodiazepines (flunitrazepam, clonazepam, RO 11 3128), but not the inactive RO 113624 , prevented the heat inacti-

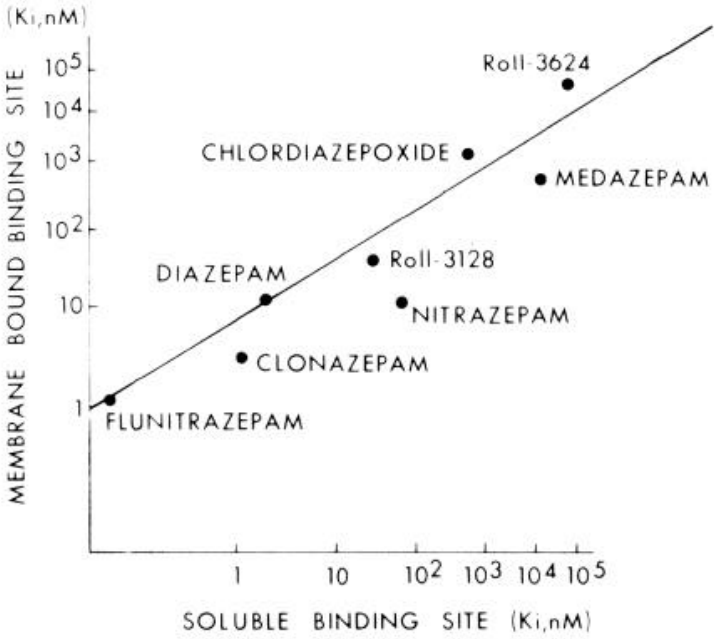

Figure 4. Inhibition of $\left[{ }^{3} \mathrm{H}\right]$ diazepam binding to solubilized and membrane-bound recognition sites by various benzodiazepines. The reaction was initiated by adding $1.5 \mathrm{~nm}\left[{ }^{3} \mathrm{H}\right]$ diazepam to the incubation mixture. Each point represents the $K_{I}\left(K_{I}=\right.$ $\left.\mathrm{IC}_{50} / 1+\left(C / K_{D}\right)\right)$ obtained from at least three series of experiments performed in triplicate. The various benzodiazepines were added directly in the incubation mixture in concentrations (C) ranging from $10^{-6}$ to $10^{-10} \mathrm{M}$. The dissociation constant used to calculate $K_{I}$ was $2.6 \mathrm{~nm}$ and $8.0 \mathrm{~nm}$ for soluble and membranebound recognition sites, respectively. The SEM was less than $10 \%$ of the mean values.

\section{TABLE IV}

GABA-induced stimulation of $\left[{ }^{3} \mathrm{H}\right]$ diazepam binding to solubilized or CSM-bound recognition sites

The CSMs treated with $0.05 \%$ Triton X-100 twice were prepared as reported in Table I. GABA was added to the incubation mixture together with $1.5 \mathrm{~nm}\left[{ }^{3} \mathrm{H}\right]$ diazepam $60 \mathrm{~min}$ before assay. Each value is the mean \pm SEM of at least three experiments performed in triplicate.

\begin{tabular}{cccc}
\hline \multirow{2}{*}{$\begin{array}{c}\text { Type of } \\
\text { Preparation }\end{array}$} & \multicolumn{2}{c}{ S.B. ${ }^{a}\left[{ }^{3} \mathrm{H}\right]$ Diazepam } & \\
\cline { 2 - 3 } & $-\mathrm{GABA}$ & $+\mathrm{GABA} 10^{-6} \mathrm{M}$ & \\
\hline & \multicolumn{2}{c}{$\mathrm{pmol} / \mathrm{mg}$ protein } & $\%$ \\
$\begin{array}{c}\text { CSM treated with } 0.05 \% \\
\quad\end{array}$ & $0.27 \pm 0.01$ & $0.40 \pm 0.01$ & $+48^{b}$ \\
$\begin{array}{c}\text { Triton X-100 } \\
\begin{array}{c}\text { Solubilized GABA.BZD } \\
\text { recognition complex }\end{array}\end{array}$ & $0.41 \pm 0.02$ & $0.75 \pm 0.08$ & $+85^{b}$ \\
$\begin{array}{c}\text { Solubilized benzodiaze- } \\
\text { pine recognition sites }\end{array}$ & $0.39 \pm 0.01$ & $0.35 \pm 0.02$ & -10 \\
\hline
\end{tabular}

${ }^{a}$ S.B., specifically bound.

${ }^{b} p<0.01$ when the group incubated in the presence of GABA is compared with the corresponding group incubated without GABA. 
TABLE V

Effects of endogenous inhibitors of $\left[{ }^{3} \mathrm{H}\right] \mathrm{GABA}$ and $\left[{ }^{3} \mathrm{H}\right]$ diazepam binding to different types of preparations of specific recognition sites

The data are expressed as specifically bound ${ }^{3} \mathrm{H}$ ligand in picomoles per mg of protein. An aliquot of "GABA-modulin" (10 $\mu \mathrm{g}$ of protein) or of the endogenous inhibitor of benzodiazepines ( $50 \mu \mathrm{g}$ of proteins) was added directly into the incubation mixture containing 40 to $60 \mu \mathrm{g}$ of solubilized recognition sites or 300 to $400 \mu \mathrm{g}$ of membrane proteins. The binding assay was performed in the presence of $1.5 \mathrm{nM}$ and $20 \mathrm{nM}\left[{ }^{3} \mathrm{H}\right] \mathrm{diazepam}$ and $\left[{ }^{3} \mathrm{H}\right] \mathrm{GABA}$, respectively. Each value is the mean $\pm \mathrm{SEM}$ of at least three experiments performed in triplicate.

\begin{tabular}{|c|c|c|c|c|c|c|}
\hline \multirow[b]{2}{*}{ Additions } & \multicolumn{3}{|c|}{$\left[{ }^{3} \mathrm{H}\right] \mathrm{GABA}$ Recognition Sites } & \multicolumn{3}{|c|}{$\left[{ }^{3} \mathrm{H}\right]$ Diazepam Recognition Sites } \\
\hline & Solubilized & $\begin{array}{l}\text { GABA.BDZ } \\
\text { Complex }\end{array}$ & $\begin{array}{l}\text { Membrane } \\
\text { Bound }\end{array}$ & Solubilized & $\begin{array}{l}\text { GABA.BDZ } \\
\text { Complex }\end{array}$ & $\begin{array}{l}\text { Membrane } \\
\text { Bound }\end{array}$ \\
\hline Control & $1.20 \pm 0.09$ & $0.70 \pm 0.06$ & $0.72 \pm 0.07$ & $0.55 \pm 0.08$ & $0.51 \pm 0.05$ & $0.30 \pm 0.02$ \\
\hline GABA-modulin & $\begin{array}{c}0.52 \pm 0.03^{a} \\
45 \%\end{array}$ & $\begin{array}{c}0.44 \pm 0.04^{b} \\
52 \%\end{array}$ & $\begin{array}{c}0.55 \pm 0.04^{b} \\
76 \%\end{array}$ & $\begin{array}{c}0.65 \pm 0.10 \\
118 \%\end{array}$ & $\begin{array}{c}0.60 \pm 0.05 \\
117 \%\end{array}$ & $\begin{array}{c}0.35 \pm 0.01 \\
116 \%\end{array}$ \\
\hline $\begin{array}{l}\text { Endogenous inhibitor of benzodiazepine } \\
\text { binding }\end{array}$ & $\begin{array}{c}1.0 \pm 0.09 \\
87 \%\end{array}$ & $\begin{array}{c}0.60 \pm 0.07 \\
86 \%\end{array}$ & $\begin{array}{c}0.65 \pm 0.07 \\
90 \%\end{array}$ & $\begin{array}{c}0.28 \pm 0.03^{a} \\
51 \%\end{array}$ & $\begin{array}{c}0.32 \pm 0.04^{b} \\
63 \%\end{array}$ & $\begin{array}{c}0.23 \pm 0.04^{a} \\
76 \%\end{array}$ \\
\hline
\end{tabular}

${ }^{a} p<0.01$ when compared to the control values according to the Student's $t$ test.

${ }^{b} p<0.05$ when compared to the control values according to the Student's $t$ test.

TABLE VI

Distribution of $\left[{ }^{3} \mathrm{H}\right] \mathrm{GABA}$ and $\left[{ }^{3} \mathrm{H}\right]$ diazepam recognition sites in the supernatant and pellet of brain cortex homogenates incubated with Triton X-100

The homogenate was prepared from fresh brain cortex with $20 \mathrm{vol}$ of $50 \mathrm{~mm}$ Tris/citrate buffer, $\mathrm{pH} 7.1$, containing $1 \%$ Triton X-100 plus the cocktail of protease inhibitors as described under "Mat ials and Methods." The homogenate was incubated for $30 \mathrm{~min}$ at $4{ }^{\circ} \mathrm{C}$ and centrifuged for $1 \mathrm{hr}$ at $10^{5} \times \mathrm{g}$. The supernatant was passed on G-100 and twice on G-25 minicolumns in order to remove endogenous GABA. Binding was measured using $80 \mathrm{~nm}\left[{ }^{3} \mathrm{H}\right] \mathrm{GABA}$ and $24 \mathrm{~nm}\left[{ }^{3} \mathrm{H}\right]$ diazepam. Each value is the mean \pm SEM of three experiments performed in triplicate. The values are not correct for the loss during the G-100 and G- 25 column chromatography. The $\left[{ }^{3} \mathrm{H}\right]$ diazepam bound to the original homogenate was $128 \pm 10 \mathrm{pmol} / \mathrm{gm}$ of cortex. To measure the number of membrane-bound GABA recognition sites, the $10^{5} \times g$ pellets were washed three times in $20 \mathrm{vol}$ of Tris buffer.

\begin{tabular}{lcc}
\hline \multicolumn{1}{c}{ Preparation } & {$\left[{ }^{3} \mathrm{H}\right] \mathrm{GABA}$} & {$\left[{ }^{3} \mathrm{H}\right]$ Diazepam } \\
\hline & \multicolumn{2}{c}{ pmol/gm cortex } \\
$10^{5} \times g$ supernatant & $68 \pm 6$ & $7 \pm 0.9$ \\
$10^{5} \times$ g pellet & $20 \pm 2$ & $9 \pm 8$ \\
\hline
\end{tabular}

vation of $\left[{ }^{3} \mathrm{H}\right] \mathrm{GABA}$ binding sites in CSM; however, these compounds failed to protect solubilized $\left[{ }^{3} \mathrm{H}\right] \mathrm{GABA}$ recognition sites from heat inactivation (see Fig. 5).

6. The half-life of the solubilized GABA recognition sites was approximately $10 \mathrm{hr}$ when the sample was maintained at 0 to $2^{\circ} \mathrm{C}$.

\section{Discussion}

Previous reports in the literature have described the solubilization of GABA or benzodiazepine binding sites (Greenlee and Olsen, 1979; Yousufi et al., 1979; Asano and Ogasawara, 1980a, b; Gavish et al., 1979; Chude, 1979; Lang et al., 1979). However, most of these studies failed to clarify whether the benzodiazepines and GABA receptors were extracted as a complex or as two separate subunits. In addition, in two studies (Yousufi et al., 1979 and Gavish and Snyder, 1980) in which the question of whether GABA and BZD binding sites can be solubilized as independent molecules has been addressed, the results reported appear to be discrepant. Yousufi et al. (1979) reported that the solubilization of benzodiazepine binding sites yields a preparation that is insensitive to GABA stimulation and, presumably, does not include GABA recognition sites; in contrast, Gavish and Snyder (1980)
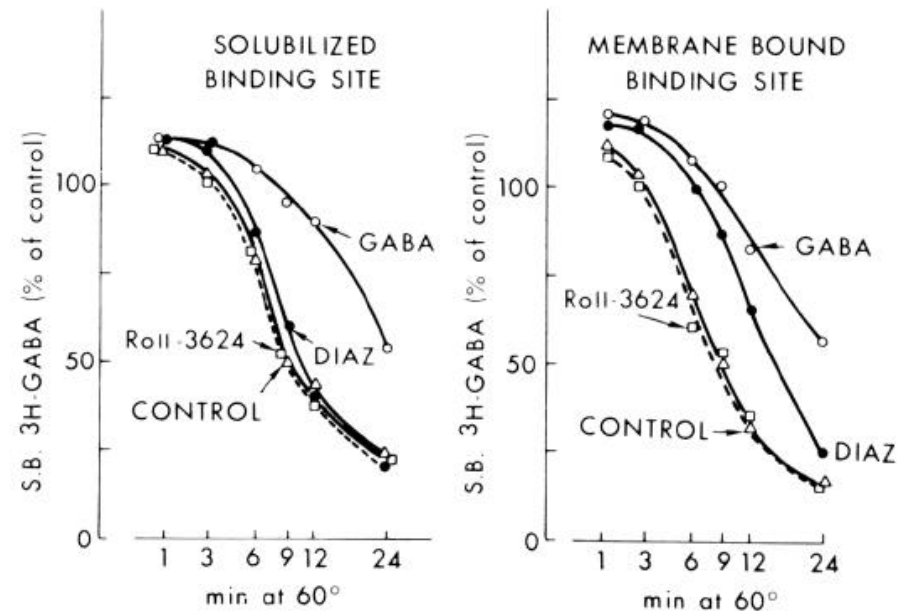

Figure 5. Thermolability of solubilized or membrane-bound GABA recognition sites; effect of $10^{-5} \mathrm{M}$ GABA, $10^{-6} \mathrm{M}$ diazepam (DIAZ), and $10^{-6} \mathrm{M}$ RO 11-3624. The recognition sites were incubated at $60^{\circ} \mathrm{C}$ for different times (see "Materials and Methods" for details). Bindings were determined in the presence of $80 \mathrm{~nm}\left[{ }^{3} \mathrm{H}\right] \mathrm{GABA}$. The basal values were $0.29 \pm 0.04$ $\mathrm{pmol} / \mathrm{mg}$ of protein and $0.41 \mathrm{pmol} / \mathrm{mg}$ of protein for membranebound and solubilized receptor sites, respectively. Each point is the mean of at least three experiments. The SEM was less than $10 \%$ of the mean values. S.B., specifically bound.

reported that GABA and benzodiazepine binding sites are solubilized as a complex because the addition of GABA increased the binding affinity of $\left[{ }^{3} \mathrm{H}\right]$ flunitrazepam by an extent similar to that observed when both recognition sites were bound to CSM.

We have been able to duplicate Gavish and Snyder's findings that GABA and benzodiazepine binding proteins can be solubilized as a complex (Guidotti et al., 1980; see also Table IV). However, by modifying the extraction procedure, we can solubilize either benzodiazepine or GABA recognition sites practically devoid of the other binding site. The rationale for setting up the modification of Gavish and Snyder's procedure evolved from our studies on GABA and benzodiazepine binding using CSM.

When CSMs were incubated with $0.05 \%$ Triton X-100 at $37^{\circ} \mathrm{C}$, the number of membrane-bound GABA recognition sites increased, while that of benzodiazepine binding sites was reduced (see also Table II). Conversely, a treatment of CSM with 1 or $2 \%$ Triton X-100 significantly reduced the number of $\left[{ }^{3} \mathrm{H}\right] \mathrm{GABA}$ binding sites present 
in CSM. Thus, the binding proteins for $\left[{ }^{3} \mathrm{H}\right]$ benzodiazepines, but not those for $\left[{ }^{3} \mathrm{H}\right] \mathrm{GABA}$, were solubilized by incubating at $37^{\circ} \mathrm{C}$ with $0.05 \%$ Triton $\mathrm{X}-100$, frozenthawed, and repeatedly washed CSM prepared from rat brain cortex. The absence of $\left[{ }^{3} \mathrm{H}\right] \mathrm{GABA}$ binding sites in this preparation of solubilized CSM proteins was proved both by the lack of high affinity binding sites for $\left[{ }^{3} \mathrm{H}\right]$ muscimol and by the absence of $\left[{ }^{3} \mathrm{H}\right]$ diazepam binding stimulation following the addition of GABA. We proved that, in this preparation, the lack of $\left[{ }^{3} \mathrm{H}\right]$ muscimol binding and that of GABA-induced stimulation of $\left[{ }^{3} \mathrm{H}\right]$ diazepam binding was not due to the presence of GABA contamination. It is possible to suggest that the GABA receptors were extracted from CSM, but they were inactivated. We do not favor this hypothesis because we still find $\left[{ }^{3} \mathrm{H}\right] \mathrm{GABA}$ binding sites in the membranes and when CSMs are extracted with higher concentrations of Triton X-100 (0.5 to $1 \%)$, the number of $\left[{ }^{3} \mathrm{H}\right] \mathrm{GABA}$ binding sites solubilized is equivalent to the number of binding sites lost from CSM. A maximal number of benzodiazepine recognition sites (approximately $50 \%$ of those located in CSM) was solubilized by incubating the CSM with $0.05 \%$ Triton $\mathrm{X}-100$ for two successive times (Table III). A third treatment of these CSMs with $0.05 \%$ or with $0.2,0.5,1$, or $2 \%$ Triton X-100 failed to produce the solubilization of additional $\left[{ }^{3} \mathrm{H}\right]$ benzodiazepine binding sites.

The characteristics of the solubilized $\left[{ }^{3} \mathrm{H}\right]$ benzodiazepine binding sites were similar to those of the sites located in CSM. They were stereospecific and the rank order of the ability of a series of benzodiazepines to displace $\left[{ }^{3} \mathrm{H}\right]$ diazepam hound to these sites was similar to that to displace the ligand bound to recognition sites located in CSM. Actually, the affinity of the solubilized sites for $\left[{ }^{3} \mathrm{H}\right]$ diazepam is 2 to 3 times higher than that of sites located in the intact CSM. A similar difference has been reporled for binding sites where GABA-BZD recognition sites are solubilized as a functional complex (Guidotti et al., 1980).

GABA binding sites virtually free of benzodiazepine binding sites were solubilized by incubating homogenates of rat brain cortex at $0^{\circ} \mathrm{C}$ with $1 \%$ Triton X-100. From Table VI, it can be calculated that approximately $70 \%$ of the GABA recognition sites can be extracted using this procedure. The advantage of using crude brain homogenate as a starting material to prepare soluble GABA recognition sites is that of utilizing the protective action of large concentrations of endogenous GABA against the rapid degradation (peptidases?) of the specific binding site for the amino acid. The recovery of solubilized GABA recognition sites can be improved by supplementing the extraction buffer with a mixture of peptidase inhibitors to prevent the rapid degradation of the solubilized GABA recognition sites.

The solubilized GABA recognition sites, similar to those bound to CSM, include two populations of sites: a high $\left(K_{D}=30 \mathrm{nM}\right)$ and a low $\left(K_{D}=280 \mathrm{nM}\right)$ affinity site for $\left[{ }^{3} \mathrm{H}\right] \mathrm{GABA}$. The binding of GABA to these sites is inhibited by bicuculline. However, unlike the GABA recognition sites located in CSM (Fig. 5), the addition of benzodiazepines fails to protect the solubilized GABA recognition sites from heat inactivation. These results indicate that the protection exerted by benzodiazepines against the heat inactivation of GABA recognition sites is mediated by the binding of benzodiazepines to specific recognition sites.

It is interesting that the procedure adopted for the solubilization of $\left[{ }^{3} \mathrm{H}\right] \mathrm{GABA}$ binding sites solubilizes a very small percentage $(8 \%)$ of the total $\left[{ }^{3} \mathrm{H}\right]$ benzodiazepine binding proteins (see Table VI). Since this extraction was carried out at 0 to $2^{\circ} \mathrm{C}$, comparison of the data of Tables III and VI suggests that the solubilization of the $\left[{ }^{3} \mathrm{H}\right]$ benzodiazepine binding sites elicited by Triton $\mathrm{X}-100$ is a temperature-dependent process.

Several reports on the solubilized binding sites of $\left[{ }^{3} \mathrm{H}\right] \mathrm{GABA}$ or $\left[{ }^{3} \mathrm{H}\right]$ benzodiazepines fail to take into consideration that the process requires the removal of endogenous modulators or ligands for these recognition sites. Because we considered this possibility as a critical point, our purification procedure includes as a last step a procedure to free the solubilized recognition sites from endogenous materials (modulator peptides, amino acids, ions) that might interfere with the binding assay. This was achieved by using the minicolumn gel filtration procedure described by Penefsky (1977). With this gel filtration technique, it was possible to remove effectively the endogenous GABA from the solubilized recognition sites even when the starting material was fresh brain cortex homogenate. In addition, since this filtration technique is rapid, the degradation of the recognition sites during this purification step is minimal. Solubilization, purification, and subsequent recombination of GABA and benzodiazepine recognition sites with purified modulatory factors extracted from brain membranes has been the final goal of our present research. We have reported in the past that it is possible to extract from CSM a material (GABA-modulin) that inhibits $\left[{ }^{3} \mathrm{H}\right] \mathrm{GABA}$ and $\left[{ }^{3} \mathrm{H}\right]$ benzodiazepine binding to CSM (Guidotti et al., 1978). The present experiments shed new light, suggesting that the inhibitor of GABA binding (GABA-modulin) is different from the compound that displaces $\left[{ }^{3} \mathrm{H}\right]$ diazepam from its high affinity binding sites. Table I shows that the characteristics of the two modulators are different. In particular, GABA-modulin is relatively thermolabile, while the inhibitor of $\left[{ }^{3} \mathrm{H}\right]$ benzodiazepine binding is highly thermoresistant. Thus, by using a thermoinactivation procedure (see "Materials and Methods") and different column chromatography techniques, it has been possible to separate GABA-modulin from the inhibitor of $\left.{ }^{3} \mathrm{H}\right]$ benzodiazepine binding.

In addition to GABA-modulin, other endogenous compounds, such as GABA (Napias et al., 1980), phospholipids (Johnston and Kennedy, 1978; Lloyd and Davidson, 1979), and a number of small molecular weight materials (Yoneda and Kuriyama, 1980; Mazzari et al., 1980), interfere with the high affinity $\left[{ }^{3} \mathrm{H}\right] \mathrm{GABA}$ binding. We have sought, therefore, to establish whether, in our GABA-modulin preparation, sufficient quantities of GABA and phospholipids were present to inhibit the high affinity binding. The data summarized in Table I, indicate that a contamination by GABA is unlikely to play a role in the inhibition of high affinity GABA binding 
by our GABA-modulin preparation because (1) in our chromatographic purification procedure, the position of GABA-modulin is different from that of GABA; (2) an amount of GABA-modulin preparation that inhibited the high affinity $\left[{ }^{3} \mathrm{H}\right] \mathrm{GABA}$ binding by more than $50 \%$ did not contain a measurable amount of GABA (less than 1 pmol); in these assay conditions, 2.5 pmol of authentic GABA produced $10 \%$ inhibition of $\left[{ }^{3} \mathrm{H}\right]$ GABA binding; (3) GABA produces a competitive inhibition of $\left[{ }^{3} \mathrm{H}\right]$ GABA binding, whereas GABA-modulin produces a noncompetitive inhibition; (4) GABA is rapidly dialyzable, whereas GABA-modulin is not; (5) GABA produces stimulation of $\left[{ }^{3} \mathrm{H}\right]$ diazepam binding, while GABA-modulin blocks the GABA-induced stimulation of $\left[{ }^{3} \mathrm{H}\right]$ diazepam binding; (6) the inhibition elicited by GABA in concentrations up to $1 \mu \mathrm{M}$ is completely destroyed by GABASE (see Napias et al., 1980), whereas the inhibition by GABA-modulin remains practically unchanged when incubated with GABASE; ( 7 ) the content of phospholipids in our preparation was below the amount that produced a significant decrease of $\left[{ }^{3} \mathrm{H}\right] \mathrm{GABA}$ binding (Toffano et al., 1978, 1980).

Several reports have suggested that the benzodiazepine recognition site may be the physiological site of action for endogenous ligands (Guidotti et al., 1978; Skolnick et al., 1978; Asano and Spector, 1979; Colello et al., 1978; Mohler et al., 1979; Davis and Cohen, 1980; Braestrup et al., 1980). The inhibitor of $\left[{ }^{3} \mathrm{H}\right]$ diazepam binding that we have used in these experiments appears to be a protein with a molecular weight greater than 1800 . These two characteristics clearly differentiate this material from the small molecular weight endogenous ligands of $\left[{ }^{3} \mathrm{H}\right]$ benzodiazepine binding sites described in other reports (Skolnick et al., 1978; Asano and Spector, 1979; Braestrup et al., 1980; Davis and Cohen, 1980; Mohler et al., 1979). It differs from the inhibitor of $\left[{ }^{3} \mathrm{H}\right]$ diazepam binding recently described by Paul et al. (1980) because of its higher molecular weight and because it does not block the GABA-induced stimulation of $\left[{ }^{3} \mathrm{H}\right]$ diazepam binding. Preliminary experiments have indicated that the inhibitor of $\left[{ }^{3} \mathrm{H}\right]$ benzodiazepine binding is unevenly distributed in various brain structures. From $100 \mathrm{mg}$ of brain cortex, an amount of the inhibitor could be extracted that has the capacity to displace 1 pmol of $\left[{ }^{3} \mathrm{H}\right]$ diazepam from its specific binding site (Massotti et al., 1980).

Both GABA-modulin and the endogenous inhibitor of $\left[{ }^{3} \mathrm{H}\right]$ diazepam binding sites are more potent in inhibiting the binding of a specific ligand when tested with solubilized receptors. These data give credence to the view that the regulation of $\left[{ }^{3} \mathrm{H}\right] \mathrm{GABA}$ and $\left[{ }^{3} \mathrm{H}\right]$ benzodiazepine recognition sites by the two modulators does not require the integrity of the membrane structure because it may occur even when the phospholipidic support for the recognition site is eliminated by extraction and solubilization of the binding sites with Triton X-100.

In conclusion, our data indicate that the recognition sites for $\left[{ }^{3} \mathrm{H}\right] \mathrm{GABA}$ and $\left[{ }^{3} \mathrm{H}\right]$ benzodiazepines and the endogenous inhibitors of $\left[{ }^{3} \mathrm{H}\right]$ GABA (GABA-modulin) and $\left[{ }^{3} \mathrm{H}\right]$ diazepam binding can be extracted from the CSM and solubilized as separate units. Since these membrane components are functionally associated in the su- pramolecular organization of GABA receptors, the "GABA receptor unit," the biochemical dissection of these components is the first step in understanding the mechanisms whereby these various molecules are operative in GABA receptor function.

\section{References}

Asano, T., and N. Ogasawara (1980a) Solubilization of the benzodiazepine receptor from rat brain. Life Sci. 26: 607-613.

Asano, T., and N. Ogasawara (1980b) Solubilization of gammaaminobutyric acid receptor from rat brain. Life Sci. 26: 11311137.

Asano, T., and S. Spector (1979) Identification of inosine and hypoxanthine as endogenous ligands for the brain benzodiazepine binding sites. Proc. Natl. Acad. Sci. U. S. A. 76: 977981.

Baraldi, M., A. Guidotti, J. P. Schwartz, and E. Costa (1979) Clonal cell lines: A model for study of benzodiazepine action at the molecular level. Science 205: 821-823.

Bertilsson, L., and E. Costa (1976) Mass fragmentographic quantitation of glutamic acid and gamma-aminobutyric acid in cerebellar nuclei and sympathetic ganglia of rats. J. Chromatogr. 118: 395-402.

Braestrup, C., M. Nielsen, and C. E. Olsen (1980) Urinary and brain beta-carboline-3-carboxylates as potent inhibitors of brain benzodiazepine receptors. Proc. Natl. Acad. Sci. U. S. A. 77 : $2288-2292$.

Chude, O. (1979) Solubilization and partial purification of the GABA receptors from mouse brain and a binding assay for solubilized receptor. J. Neurochem. 33: 621-629.

Colello, G. D., D. M. Hockenbery, H. B. Bosmann, S. Fuchs, and K. Folkers (1978) Competitive inhibition of benzodiazepine binding by fractions from porcine brain. Proc. Natl. Acad. Sci. U. S. A. 75: 6319-6323.

Costa, E., and A. Guidotti (1979) Molecular mechanisms in the receptor action of benzodiazepines. Annu. Rev. Pharmacol. Toxicol. 19: 531-545.

Davis, L. G., and R. K. Cohen (1980) Inhibition of [ $\left.{ }^{3} \mathrm{H}\right]$ diazepam binding by an endogenous fraction from rat brain synaptosomes. J. Pharm. Pharmacol. 32: 218-219.

Enna, S. J., and S. H. Snyder (1977) Influences of ions, enzymes and detergents on gamma-aminobutyric acid: Receptor binding in synaptic membranes of rat brain. Mol. Pharmacol. 13: 442-453.

Folch, J., M. Lees, and G. H. Sloane Stanley (1957) A simple method for the isolation and purification of total lipides from animal tissues. J. Biol. Chem. 226: 497-509.

Gavish, M., and S. H. Snyder (1980) Soluble benzodiazepine receptors: GABAergic regulation. Life Sci. 26: 579-582.

Gavish, M., S. L. Chang, and S. H. Snyder (1979) Solubilization of histamine H-1, GABA and benzodiazepine receptors. Life Sci. 25: 783790 .

Glowinski, J., and L. L. Iversen (1966) Regional studies of catecholamines in rat brain. I. The disposition of ${ }^{3} \mathrm{H}$-norepinephrine, ${ }^{3} \mathrm{H}$-dopamine and ${ }^{3} \mathrm{H}$-Dopa in various regions of the brain. J. Neurochem. 13: 655-699.

Greenlee, D. V., and R. W. Olsen (1979) Solubilization of gamma-aminobutyric acid receptor protein from mammalian brain. Biochem. Biophys. Res. Commun. 88: 380-387.

Guidotti, A., G. Toffano, L. Grandison and E. Costa (1977) Second messenger responses and the regulation of high affinity receptor binding to study pharmacological modifications of GABAergic transmission. In Amino Acids as Chemical Transmitters, F. Fonnum, ed., pp. 517-530, Plenum Press, New York.

Guidotti, A., G. Toffano, and E. Costa (1978) An endogenous 
protein modulates the affinity of GABA and benzodiazepine receptors in rat brain. Nature 275: 553-555.

Guidotti, A., M. Massotti, and E. Costa (1980) GABA-modulin regulates solubilized benzodiazepine and GABA recognition sites. In Psychopharmacology and Biochemistry of Neurotransmitter Receptors, R. W. Olsen and H. Yamamura, eds., pp. 655-660, Elsevier-North Holland, New York.

Johnston, G. A. R., and S. M. E. Kennedy (1978) GABA receptors and phospholipids. In Amino Acids as Chemical Transmitters, F. Fonnum, ed., pp. 507-516, Plenum Press, New York.

Lang, B., E. Barnard, L. Chang, and O. Dolly (1979) Putative benzodiazepine receptor: A protein solubilized from brain. FEBS Lett. 104: 149-153.

Lloyd, K. G., and L. Davidson (1979) $\left[{ }^{3} \mathrm{H}\right] \mathrm{GABA}$ binding in brains from Huntington's chorea patients: Altered regulation by phospholipids? Science 215: 1147-1149.

Lowry, O. H., N. J. Rosebrough, A. L. Farr, and R. J. Randall (1951) Protein measurement with Folin phenol reagent. J. Biol. Chem. 193: 265-275.

Massotti, M., and A. Guidotti (1980) Endogenous regulators of benzodiazepine recognition sites. Life Sci. 27: 847-854.

Massotti, M., A. Guidotti, and E. Costa (1980) 'The regulation of benzodiazepine recognition sites by endogenous modulators. In GARA and Renzodiazepine Receptors, E. Costa, G. Di Chiara, and G. L. Gessa, eds., pp. 19-26, Raven Press, New York.

Mazzari, S., A. Leon, M. Massotti, A. Guidotti, and E. Costa (1980) Assay in GABA-modulin activity in brain extracts: Resolution of inherent difficulties. In Psychopharmacology and Biochemistry of Neurotransmitter Receptors, R. W. Olsen and M. Yamamura, eds., pp. 607-615, Elsevier-North Holland, New York.

Mohler, H., P. Polc, R. Cumin, L. Pieri, and R. Kettler (1979) Nicotinamide is a brain constituent with benzodiazepine like action. Nature 278: 563-565.

Mohler, H., J. G. Richards and J. Y. Wu (1980a) Autoradiographic localization of benzodiazepine receptors in immunocytochemically identified GABAergic synapses. Neurobiology (Copenh.), in press.

Mohler, H., J. Y. Wu, and J. G. Richards (1980b) Benzodiazepine receptors: Autoradiographical and immunocytochemical evidence for their localization in regions of GABAergic synaptic contacts. In $G A B A$ and Benzodiazepine Receptors, E. Costa, G. Di Chiara, and G. L. Gessa, eds., pp. 139-146, Raven Press, New York.

Napias, C., M. O. Bergman, P. C. Van Ness, D. V. Greenlee, and R. W. Olsen (1980) GABA binding in mammalian brain:
Inhibition by endogenous GABA. Life Sci. 27: 1001-1011.

Okada, Y., C. Nitsch-Hassler, J. S. Kim, J. Bak, and R. Hassler (1971) Role of gamma aminobutyric acid (GABA) in the extrapyramidal motor system. Exp. Brain Res. 13: 514-518.

Paul, S., P. Marangos, M. Brownstein, and P. Skolnick (1980) Demonstration and characterization of an endogenous inhibitor of GABA enhanced $\left[{ }^{3} \mathrm{H}\right]$ diazepam binding from bovine cerebral cortex. In GABA and Benzodiazepine Receptors, E. Costa, G. Di Chiara, and G. L. Gessa, eds., pp. 103-110, Raven Press, New York.

Penefsky, H. S. (1977) Reversible binding of Pi by beef heart mitochondrial adenosine triphosphatase. J. Biol. Chem. 252: 2891-2899.

Rosenthal, H. E. (1967) A graphic method for the determination and presentation of binding parameters in a complex systern. Anal. Biochem. 20: 525-532.

Schmid, R., J. S. Hong, J. Meek and E. Costa (1980) Effect of kainic acid on the hippocampal content of putative transmitter amino acids. Brain Res. 200: 355-362.

Sieghart, W., and M. Karobath (1980) Molecular heterogeneity of benzodiazepine receptors. Nature 286: 285-287.

Skipski, V. P., and M. Barclay (1969) Thin layer chromatography of lipids. Methods Enzymol. 14: 530-598.

Skolnick, P., P. J. Marangos, and F. K. Goodwin (1978) Identification of inosine and hypoxanthine as endogenous inhibitors of ${ }^{3} \mathrm{H}$-diazepam binding in central nervous system. Life Sci. 23: 1473-1480.

Tallman, J. F., J. W. Thomas, and D. W. Gallager (1978) GABAergic modulation of the benzodiazepine binding site sensitivity. Nature 274: 383-385.

Tallman, J. F., S. M. Paul, P. Skolnick, and D. W. Gallager (1980) Receptors for the age of anxiety: Pharmacology of the benzodiazepines. Science 207: 274-281.

Toffano, G., A. Guidotti, and E. Costa (1978) Purification of an endogenous protein inhibitor for the high affinity binding of gamma aminobutyric acid to synaptic membranes of rat brain. Proc. Natl. Acad. Sci. U. S. A. 75: 4024-4028.

Toffano, G., C. Aldino, M. Balzano, A. Leon, and G. Kirschner (1980) Role of membrane lipids on the regulation of GABA recognition sites. GABA and Benzodiazepine Receptors, E. Costa, G. Di Chiara, and G. L. Gessa, eds., pp. 169-179, Raven Press, New York.

Yoneda, Y., and K. Kuriyama (1980) Presence of low molecular weight endogenous inhibitor on ${ }^{3} \mathrm{H}$-muscimol binding in synaptic membranes. Nature 285: 670-673.

Yousufi, M. A. K., J. W. Thomas, and J. F. Tallman (1979) Solubilization of benzodiazepine binding sites from rat cortex. Life Sci. 25: $463-470$. 